\title{
Stock Price and Performance of Indonesian Banking, Case Study for Period of 2015-2017
}

\author{
Cornelius Candra Adi Wibowo', Agus Sukoco² \\ Narotama University \\ corneliuscandra.adiwibowo@gmail.com
}

\begin{abstract}
The purpose of this study is to analyze the effect of Return On Assets, Return On Equity and Earning Per Share to Price Book Value and stock prices of Banking Companies listed in Indonesia Stock Exchange (IDX) during 2015-2017. This study analyzes ratios of financial statements of banking companies and their impact on stock prices. The population of this research is Banking Companies listed in IDX during 2015-2017. Samples used are as many as 43 Banking companies with census method. The analytical technique used is Partial Least Square. The financial statements used are from the Indonesia Stock Exchange website and tested with the SmartPLS 3.0 application. Result of this study is ROE and EPS have a significant and positive influence on PBV. ROE, EPS and PBV have significant and positive influence on stock price. However DER has no significant effect on PBV and Stock Price.

Keywords: ROE, EPS, DER, PBV and stock price.
\end{abstract}

\section{INTRODUCTION}

The capital market is a place between investors and issuers through buying and selling shares and bonds. Therefore the capital market has a very important role in the movement of the economy of a company because of capital market activities, the company hopes to get additional capital. And investors expect dividends and capital gains. The banking sector shares are shares that are of great interest to investors because the banking sector plays a very important role in increasing national economic growth. The existence of banks in Indonesia will last a long time and will continue to grow over time.

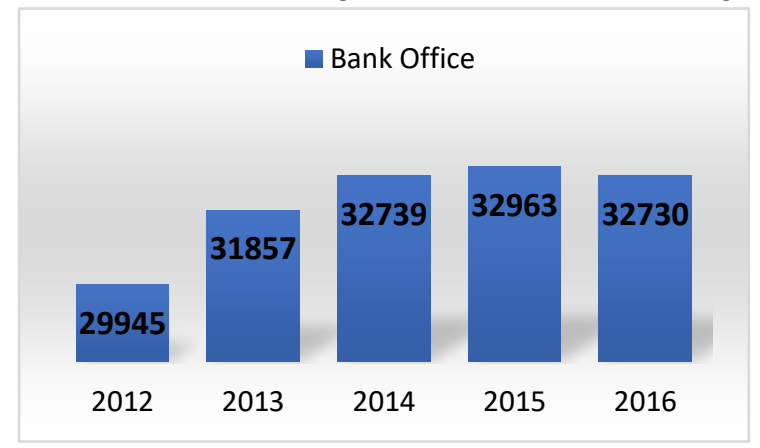

Fig 1. The Number Of Bank Offices In Indonesia

In figure 1 , it is explained that in five years, the number of bank offices in Indonesia increased by $13.40 \%$. In 2012 the number of bank offices amounted to 29,945 units and increased to 32,730 in 2016 .. It can be concluded that the banking sector has a high investment value and has good profit expectations for investors. But now there are still many difficulties obtained by investors to find out information about a banking company in Indonesia. The most available information for investors in the capital market is financial statements. This is because every public banking company is required to issue financial statements less than three months after the close of the financial year. With fundamental analysis of financial statements, investors can find out the company's value, financial condition, company performance, risk of investing and predict the company's stock price.

The value of the company will be reflected in the market price of shares owned. The value of shares will increase if the value of the company increases which is marked by a high return on investment to shareholders. Company value is the work of management from several dimensions including net cash flow from investment decisions, growth and company capital costs [1]. PBV (Price Book Value) is a ratio 
that describes how much the market values the book value of shares of a company [2]. In measuring the performance of a company, investors usually see financial performance reflected in a variety of ratios. The ratio commonly used as a measure of the company's financial performance is Return On Equity (ROE). Return On Equity, measures the ability of a company to obtain profits available to the company's shareholders [3]. There is also a Debt to Equity Ratio (DER). This ratio is used, to measure total debt with total equity. This ratio, calculated by, how to compare, total debt, company, including debt, current, total equity [4]. Meanwhile, there is another ratio, namely Earning Per Share (EPS). Earning Per Share is a form of giving benefits given to shareholders of each share owned [4]. The author chooses the ROE ratio as a factor that influences stock prices because ROE is a ratio that represents the return on all company capital. Meanwhile, EPS is chosen because EPS shows how many rupiahs the profits investors receive on each share. Then DER was chosen to measure the company's debt. PBV is chosen to reflect the value of a company.

\section{LITERATURE REVIEW}

Research conducted by Sanjaya, Dwiatmo, \& Endang (2015) entitled "The Effect of Return On Equity (ROE), Debt Ratio (DR), Debt To Equity Ratio (DER), Earning Per Share (EPS) Against Stock Prices (Study on , Food and Beverage Companies, Registered on the Stock Exchange, Indonesia for the Period 2011-2013) ". The results of this study are simultaneously ROE, DR, DER, EPS which significantly influence stock prices, but partially only ROE has a significant effect, EPS, DR, DER have no significant effect. Partial analysis results can be explained that: ROE has a significant effect on stock prices. DR does not have a significant effect on stock prices. DER does not affect stock prices. EPS does not affect stock prices [5].

The research conducted by Khairudin \& Wandita (2017) is entitled "Analysis Of The Effect Of Profitability Ratio, Debt To Equity Ratio (DER) And Price To Book Value (PBV) On Stock Company Price In Indonesia)". The results showed that profitability ratios (return on equity, earnings per share) and price to book value had a positive and significant effect on stock prices, while the debt to equity ratio had a negative and significant effect on stock prices [6].

\section{CONCEPTUAL FRAMEWORK}

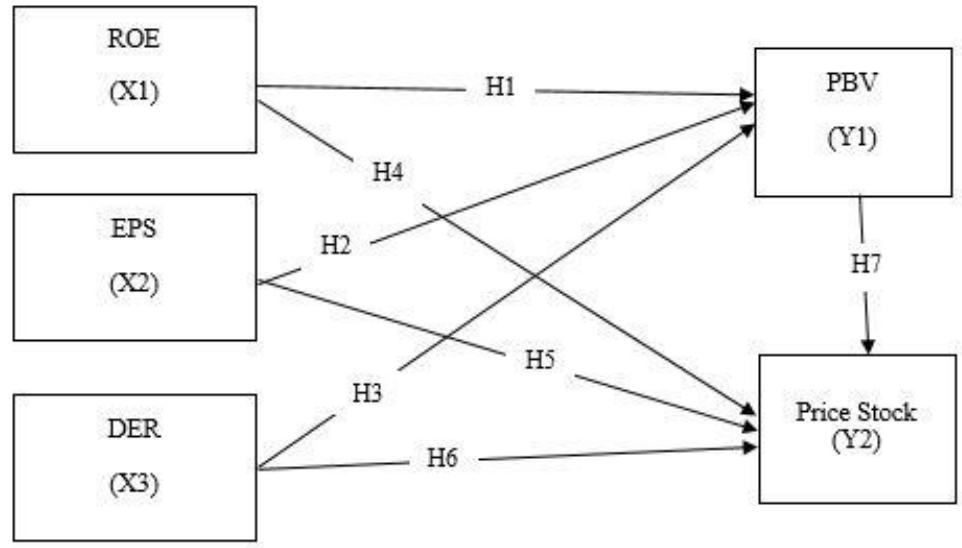

Fig 2. Conceptual Framework

\section{HYPOTHESIS}

Based on the theoretical basis and the framework of thinking that has been described above, the hypothesis of this study are:

H1: Ratio On Equity (ROA) has a positive and significant effect on Price Book Value (PBV).

H2: Earning Per Share (EPS) has a positive and significant effect on Price Book Value (PBV). 
H3: Debt to Equity Ratio (DER) has a positive and significant effect on Price Book Value (PBV).

H4: Ratio On Assets (ROA) has a positive and significant effect on stock prices.

H5: Earning Per Share (EPS) has a positive and significant effect on stock prices.

H6: Debt to Equity Ratio (DER) has a positive and significant effect on stock prices.

H7: Price Book Value (PBV) has a positive and significant effect on stock prices.

\section{RESEARCH METHOD}

This research is quantitative research, namely research conducted to compare a variable (object of research), between different subjects or different times and find a cause-effect relationship [7]. The population that became the object of this study were 43 banking companies registered with the Indonesian Securities Exchange (BEI) in the period 2015-2017. The method of determining the sample used in this study is the census method, namely if all members of the population are used as samples. The type of data used in this study is secondary data obtained from the Indonesia Stock Exchange website (www.idx.co.id). The required data is the 2015-2017 financial report in the form of a summary of company performance that can be calculated ROE, EPS, DER, PBV and stock price. Data analysis of this study was using Partial Least Square (PLS) processed with Smart PLS 3.0 software. Partial Least Square (PLS) is a powerful analytical method because it does not assume data must be of a certain scale, small number of samples. The purpose of Partial Least Square (PLS) is to help researchers get the value of latent variables for prediction purposes [8]. PLS analysis carried out is a measurement model (outer model) and a structural model (inner model). Analysis of the outer model is done to ensure that the measurements used are feasible to be used as measurements (valid and reliable). Analysis of inner models is carried out to ensure that the models are robust and accurate. The structural model was evaluated using $\mathrm{R}$-square for the dependent construct, $\mathrm{p}$ value and t test for significance of the structural path parameter coefficients.

\section{RESULT AND DISCUSSION}

\subsection{Descriptive Statistics}

Table 1. Descriptive Statistics

\begin{tabular}{lcccc}
\hline & $\mathrm{N}$ & Minimum & Maximum & Mean \\
\hline ROE & 129 & $-53,53$ & 73,10 & 5,4841 \\
EPS & 129 & $-484,83$ & 1371,32 & 119,7918 \\
DER & 129 &, 73 & 22,46 & 6,1622 \\
PBV & 129 &, 26 & 5,45 & 1,5102 \\
Stock Price & 129 & 51,00 & 20300,00 & 1790,1395 \\
Valid N (listwise) & 129 & & & \\
\hline
\end{tabular}

Based on the table 1 above the results of the descriptive statistics calculation show that of the 43 banking companies during the 3 years of observation, the average value of ROE in banking companies listed on the Indonesia Stock Exchange in 2015 - 2017 during the observation period was 5.48 with a maximum value of $-53,53$ and maximum value of 73.10. The average EPS value for banking companies listed on the Indonesia Stock Exchange in 2015-2017 during the observation period amounted to 10017 rupiahs with a maximum value of -48483 rupiah and a maximum value of 1371.32. The average DER value of banking companies listed on the Indonesia Stock Exchange in 2015 - 2017 during the observation period is 6.16 with a value of manimum 0.73 and a maximum value of 22.46 . The average value of PBV in banking companies listed on the Indonesia Stock Exchange in 2015 - 2017 during the observation period is 1.51 rupiah with a maximum value of 0.26 and a maximum value of 5.54. The average value of stock prices in banking companies listed on the Indonesia Stock Exchange in 2015 - 2017 during the observation period amounted to 1790 rupiahs with a maximum value of 51 rupiah and a maximum value of 20300 . 


\subsection{Evaluation of Measurement Model (Outer Model)}

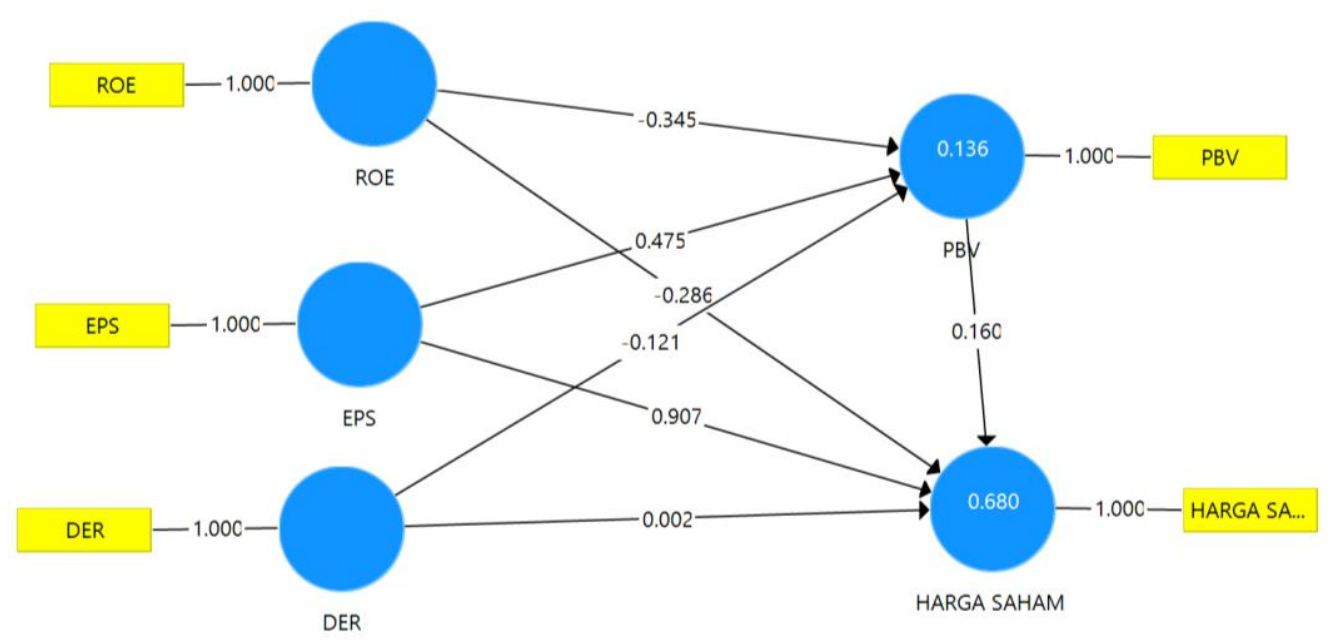

Fig. 3. Output SmartPLS.

Loading Factor describes how much the indicators relate to each construct. The path diagram above shows that all indicators have a loading factor of 1,000 which means that all indicators are valid because the value of the loading factor meets the criteria, namely the value of the loading factor construct must be above 0.70 . These results indicate a good relationship between the indicators and each construct.

The second examination of convergent validity is to look at the value of cronbach's alpha and composite reliability. The results are as follows:

Table 2. Composite Reliability and Average Variance Extracted

\begin{tabular}{ccccc}
\hline & $\begin{array}{c}\text { Cronbach's } \\
\text { Alpha }\end{array}$ & rho_A & $\begin{array}{c}\text { Composite } \\
\text { Reliability }\end{array}$ & $\begin{array}{c}\text { Average Variance } \\
\text { Extracted (AVE) }\end{array}$ \\
\hline DER & 1,000 & 1,000 & 1,000 & 1,000 \\
EPS & 1,000 & 1,000 & 1,000 & 1,000 \\
STOCK PRICE & 1,000 & 1,000 & 1,000 & 1,000 \\
PBV & 1,000 & 1,000 & 1,000 & 1,000 \\
ROE & 1,000 & 1,000 & 1,000 & 1,000 \\
\hline
\end{tabular}

The value of Cronbach's Alpha and Composite Reliability above 0.7 indicates the reliability of a high gauge means that the gauge of each construct is highly correlated. The third check of convergent validity is to see the value of AVE. AVE values above 0.5 are highly recommended. From table 4.3 the AVE value of all extracts is 1 or above 0.5 .

After convergent validity evaluation is fulfilled, then it is an examination of discriminant validity which includes cross loading and comparing with AVE roots with correlation between extracts. Here are the results of Cross loading .

Table 3. Cross Loading Value

\begin{tabular}{cccccc}
\hline & DER & EPS & STOCK PRICE & PBV & ROE \\
\hline DER & 1,000 & 0.248 & 0.189 & $-0,042$ & 0.083 \\
EPS & 0.248 & 1,000 & 0.766 & 0.230 & 0.655 \\
STOCK PRICE & 0.189 & 0.766 & 1,000 & 0.386 & 0.274 \\
PBV & $-0,042$ & 0.230 & 0.386 & 1,000 & $-0,041$ \\
ROE & 0.083 & 0.655 & 0.274 & $-0,041$ & 1,000 \\
\hline
\end{tabular}

From the results of cross loadings all indicators correlate highly with each of the constructs. Cross loading explains how strong the indicators affect each latent variable (construct). Based on the table above indicates that the latent construct predicts its own indicator better than other latent 
indicators. Based on the analysis, it can be interpreted that it has fulfilled discriminant validity . Indicator can be said to have good reliability if the value is greater than 0.70 [9]. The second method for testing discriminant validity is looking at the AVE root value and comparing it with the correlation between the extracts. The result is as follows:

Table 4. Discriminant Validity

\begin{tabular}{cccccc}
\hline & DER & EPS & STOCK PRICE & PBV & ROE \\
\hline DER & 1,000 & & & & \\
EPS & 0.248 & 1,000 & & & \\
STOCK PRICE & 0.189 & 0.766 & 1,000 & & \\
PBV & $-0,042$ & 0.230 & 0.386 & 1,000 & \\
ROE & 0.110 & 0.622 & 0.269 & $-0,063$ & 1,000 \\
\hline
\end{tabular}

Table 5. AVE value

\begin{tabular}{cc}
\hline & $\begin{array}{c}\text { Average Variance } \\
\text { Extracted (AVE) }\end{array}$ \\
\hline DER & 1,000 \\
EPS & 1,000 \\
STOCK PRICE & 1,000 \\
PBV & 1,000 \\
ROE & 1,000 \\
\hline
\end{tabular}

Based on the table above, it can be seen that the AVE root for each DER construct is 1 . For the DER variable, AVE root value (1) is still higher than the correlation between DER and EPS ( 0.248 ), STOCK PRICE ( 0.189$)$, PBV ( -0.042$)$ and ROE $(0,110)$. This result is also evident in other variables as well so that for all DER, EPS, STOCK PRICE, PBV and ROE variables meet good discriminant validity requirements.

\subsection{Evaluation of Structural Models (Inner Model)}

After checking the measurement model is met, then the next is an examination of the structural model. These checks include the significance of the relationship line and the value of R Square (R 2) to see the results of the evaluation of structural models, especially the significance of the moderating variable. The value of R 2 aims to find out how much the independent variable influences the dependent variable. R 2 value can be seen in table 4.7. To see the contribution whether given the moderating variable to the model can be seen from the effect of the interaction.

Table 6. R Square

\begin{tabular}{cc}
\hline & R Square \\
\hline STOCK PRICE & 0.680 \\
PBV & 0.136 \\
\hline
\end{tabular}

In this study consisted of 5 variables namely independent variables as many as 3 variables, namely Return On Equity (X1), Earning Per Share (X2), Debt to Equity Ratio (X3), intervening variables as much as 1 variable, Price Book Value (Y1), and the dependent variable is 1, namely the Stock Price (Y2). Table 8 shows the value of R Square for the Price Book Value variable (Y1) obtained at 0.136 , for the Stock Price variable (Y2) obtained a value of 0.680 . These results indicate that $68 \%(0.680)$ of the Stock Price variable (Y2) can be influenced by the variable Return On Equity (X1), Earning Per Share (X2), Debt to Equity Ratio (X3), while Price Book Value (Y1) with a percentage value of 13.6\% (0.136).

\subsection{Results of Direct Influence}

Table 7. Path coefficient

\begin{tabular}{cccccc}
\hline & $\begin{array}{c}\text { Original } \\
\text { Sample } \\
(\mathrm{O})\end{array}$ & $\begin{array}{c}\text { Sample } \\
\text { Mean } \\
(\mathrm{M})\end{array}$ & $\begin{array}{c}\text { Standard } \\
\text { Deviation } \\
(\text { STDEV })\end{array}$ & $\begin{array}{c}\text { T Statistics }(\mid \\
\text { O / STDEV } \\
\mid)\end{array}$ & P Values \\
\hline ROE -> PBV & 0.345 & 0.313 & 0.155 & 2.231 & 0.028 \\
EPS -> PBV & 0.475 & 0.464 & 0.116 & 4,093 & 0,000 \\
\hline
\end{tabular}




\begin{tabular}{cccccc}
\hline DER -> PBV & -0.121 & -0.110 & 0.085 & 1,421 & 0.158 \\
ROE -> STOCK PRICE & 0.286 & 0.299 & 0.151 & 1,900 & 0.060 \\
EPS -> STOCK PRICES & 0.907 & 0.939 & 0.089 & 10.156 & 0,000 \\
DER -> STOCK PRICE & 0.002 & $-0,010$ & 0.056 & 0.042 & 0.967 \\
PBV -> STOCK & 0.160 & 0.161 & 0.062 & 2,582 & 0.011 \\
$\quad$ PRICES & & & & \\
\hline
\end{tabular}

Hypothesis testing will be done by means of boostrapping to see t-statistics and p-values with a significant level of $5 \%(1,979)$. So that the acceptance criteria or rejection of the hypothesis are HA accepted and $\mathrm{H} 0$ rejected when t-statistics show $>1.979$, and to reject or accept the hypothesis using probability values, then Ha will be accepted if p-value $<0.05$.

\section{Hypothesis Testing 1 (Significant Effect of Return On Equity on Price Book Value )}

Return On Equity has a positive and significant effect on Stock Prices with the value of $\mathrm{t}$ count statistic $>\mathrm{t}$ table $1,979(2,231>1,979)$. This can be seen from the statistical $\mathrm{t}$ value of 2.231 and the p-value below 0.050 which means that the construct of Return On Equity has an effect on the construct of the Stock Price. This means that Hypothesis 1 is accepted. The results of this study are supported by previous research conducted by Marlina, (2013) which states that Return On Equity has a positive and significant effect on Price Book Value [10]. The ROE growth shows that the company's prospects are getting better because it means that there is a potential increase in profits obtained by the company so that it will increase investor confidence and will facilitate the company's management to attract capital in the form of shares. Increasing Return On Equity (ROE) will increase Price to Book Value. If the company's shares are traded on the stock exchange, the high and low Return on Equity will affect the level of demand for the shares in the stock and the selling price. This is because Return on Equity is a benchmark of profitability where shareholders want to know the level of probability of the share capital they have planted in the company and the amount of profit earned.

\section{Hypothesis Testing 2 (Significant Earing Per Share Effect on Price Book Value)}

Earning Per Share (X2) with Price Book Value (Y1) shows a p-value of 0,000 with a t value of 4,093. This value is greater than t table $(1,979)$ and $p$-value below 0.050 . This result means that Earning Per Share (X2) has a significant influence on Price Book Value (Y1). This means that Hypothesis 2 is accepted. The results of this study are supported by previous research conducted by Marlina, (2013) which states that Earning Per Share has a positive and significant effect on Price Book Value [10]. Earning Per Share (EPS) is the result of the company's net income (Net Income) divided by the number of shares outstanding (outstanding shares). The higher Earning Per Share shows the higher profit the company gets. When investors evaluate the performance of a company, investors are not enough to just know whether a company's income has increased or decreased, investors also need to look at how changes in income have an impact on their investment. The results of this study indicate that rising Earning per Share (EPS) reflects the return on investment per share, so that investor confidence increases and stock prices also increase, the eventual impact of Price Book Value (PBV) also increases. Conversely, if Earning Per Share (EPS) falls, investors are reluctant to buy shares, this condition will result in a decrease in Price to book value $(\mathrm{PBV})$.

\section{Testing of Hypothesis 3 (Significant Effect of Debt to Equity Ratio on Price Book Value )}

The results of testing the third hypothesis prove that the effect of the variable Debt to Equity Ratio (X3) with Price Book Value (Y1) indicates the p-value of 0.158 with a $t$ value of 1,421 . This value is smaller than $t$ table (1.979) and $p$-value above 0.050 . This result means that Debt to Equity Ratio (X3) does not have a significant effect on Price Book Value (Y1). This means that Hypothesis 3 is rejected. The results of this study are supported by previous research conducted by Nuraeni, Lau, \& Haryadi, (2016) stating that the Debt to Equity Ratio has a negative and not significant effect on the Price Book Value [11]. The existence of a negative relationship from the DER variable to PBV shows the more DER, the lower the PBV and no significant effect. This is because no matter how much use of debt will not affect the value of the company because 
the use of debt will cause the cost of ordinary equity to rise at the same level. With the higher debt used by the company to finance the company's operations it will reduce the value of PBV because with a high level of debt, the company's burden is also large.

\section{Testing of Hypothesis 4 (Significant Effect of Return On Equity on Stock Prices )}

The results of testing the fourth hypothesis prove that the influence of the Return On Equity (X1) variable with the Stock Price (Y2) shows a p-value of 0.060 with a t value of 1,900 . This value is smaller than table (1.979) and $\mathrm{p}$-value above 0.050 . This result means that Return On Equity (X1) does not have a significant effect on Stock Prices (Y1). This means that Hypothesis 4 is rejected. This result is the same as the research conducted by Rusli \& Dasar, (2014) which states that Return On Equity has no significant effect on stock prices [12]. This happens because it turns out that the company's profit which is one indicator of the calculation of $\mathrm{ROE}$ is not the only indicator in making stock price decisions. Capital costs are also strongly influenced by interest rates. In addition, differences in technical calculations, company size, conditions of the Indonesian money market, internal factors other than economic fundamentals, interest rates, devaluations, economic growth, government spending and money supply, sales, sales growth, costs, cash dividends, social conditions, politics and economics are factors that must be considered in determining stock prices

\section{Testing of Hypothesis 5 (Significant Effect of Earing Per Share on Stock Prices)}

The results of the fifth hypothesis testing prove that the influence of the Earning Per Share (X2) variable with the Stock Price (Y2) shows the p-value of 0,000 with a $t$ value of 10.156 . This value is greater than t table $(1,979)$ and $p$-value below 0.050 . This result means that Earning Per Share (X2) has a significant influence on the Stock Price (Y2). This means that Hypothesis 5 is accepted. The results of this study are supported by previous research conducted by Febrioni, (2016) stating that Earning Per Share has a positive and significant effect on Stock Prices [13]. EPS is the amount of profit or profit obtained in one period for each share. EPS is also an illustration of the company's ability to generate net profits in every share. Increased EPS indicates that the company managed to increase investor profits. This prompted investors to increase the amount of capital invested in the company's shares. An increase in the number of requests for stocks pushed up stock prices. Thus, if EPS increases, the market will respond positively with the increase in stock prices. EPS shows the company's ability to generate net profits in each of its shares. The higher the value of EPS means the better because it will increase stock prices and this will benefit the company.

\section{Testing of Hypothesis 6 (Significant Effect of Debt to Equity Ratio on Stock Prices)}

The results of the sixth hypothesis testing prove that the influence of the Debt to Equity Ratio variable (X3) with the Stock Price (Y2) shows the p-value of 0.967 with a t value of 0,042 . This value is smaller than t table (1.979) and p-value above 0.050. This result means that Debt to Equity Ratio (X3) does not have a significant effect on the Stock Price (Y2). This means Hypothesis 6 is rejected. The results of this study are supported by previous research conducted by Sanjaya et al., (2015) which states that Debt to Equity Ratio has a negative and not significant effect on Stock Prices [5]. This is due to the fact that many of the company's management chose to use capital costs that only came from internal companies and did not recommend financing external capital from debt. They assume that the capital obtained from debt will have a bad effect in the future on the value of the company because debt contains risks.

\section{Testing of Hypothesis 7 (Significant Effect of Price Book Value on Stock Prices)}

The results of testing the seventh hypothesis prove that the effect of the Price Book Value variable (Y1) with the Stock Price (Y2) shows a p-value of 0.011 with a t value of 2.582 . This value is greater than t table $(1,979)$ and $p$-value below 0.050 .This result means that Price Book Value (Y1) has a significant influence on the Stock Price (Y2).This means that Hypothesis 7 is accepted. PBV ratio is a ratio used to measure the performance of stock market prices on the value of the book. Price to Book Value (PBV) relationship to stock prices is 
positive, namely the higher PBV ratio, the higher the stock price, because companies are able to create value for shareholders, where the higher the level of market confidence in the prospects of the company, so that the demand for these shares rose and boosted the company's stock price [14].

\section{CONCLUSION AND RECOMMENDATION}

This research is conducted to analyze the effect of Return On Assets, Return On Equity and Earning Per Share to Price Book Value and stock prices of Banking Companies listed in Indonesia Stock Exchange (IDX) during 2015-2017. Based on the results of research and discussion analysis has been done, it can be concluded as follows:

1. Ratio On Equity (ROA) has a positive and significant effect on Price Book Value (PBV).

2. Earning Per Share (EPS) has a positive and significant effect on Price Book Value (PBV).

3. Debt to Equity Ratio (DER) has a negative and not significant effect on Price Book Value (PBV)

4. Ratio On Assets (ROA) has a positive and significant effect on stock prices.

5. Earning Per Share (EPS) has a positive and significant effect on stock prices.

6. Debt to Equity Ratio (DER) has a negative and not significant effect on stock prices.

7. Price Book Value (PBV) has a positive and significant effect on stock prices.

Based on the research results and conclusions that have been stated above, the researcher propose suggestions as follows:

1. For the next research, it is expected to be able to use a longer research period and add company financial variables or ratios that have not been included in this research model.

2. For investors who will invest in stocks on the Indonesia Stock Exchange, researchers suggest analyzing each movement of Return On Equity, Earning Per Share, and Price Book Value in predicting stock price movements so that investors can determine the right momentum in making buying decisions, hold or hold shares.

3. For companies, it is better to improve their financial performance so they can generate profits that continue to increase every year because investors tend to pay attention to how much profit is the right of the owner of the capital (shares) and how much return on an investment per share and see the value of the company.

\section{REFERENCES}

[1] H. P. Aries, Valuasi Perusahaan. Jakarta Pusat: PPM, 2011.

[2] Fakhruddin and Darmadji, Pasar Modal di Indonesia, 3rd ed. Jakarta: Salemba, 2011.

[3] A. Sartono, Menejemen Keuangan Teori dan Aplikasi, 4th ed. Yogyakarta: BPFE, 2010.

[4] Kasmir, Dasar-Dasar Perbankan, 1st ed. Jakarta: PT Raja Grafindo Persada, 2007.

[5] T. Sanjaya, Dwiatmo, and M. G. W. Endang, "Pengaruh Return On Equity ( Roe ), Debt Ratio (Dr), Debt To, Equity Ratio ( Der ), Earning Per Share ( Eps ) Terhadap Harga Saham ( Studi pada perusahaan Food and Beverage yang terdaftar di Bursa Efek Indonesia Periode 2011-2013)," J. Adm. Bisnis, vol. 23, no. 1, pp. 1-7, 2015.

[6] Khairudin and Wandita, “Analisis Pengaruh Rasio Profitabilitas, Debt To Equity Ratio (DER) Dan Price To Book Value (PBV) Terhadap Harga Saham Perusahaan Pertambangan Di Indonesia," J. Akunt. Keuang., vol. 8, no. 1, pp. 68-84, 2017.

[7] C. Marzuki, Metodologi Riset. Jakarta: Erlangga, 1999.

[8] I. Ghozali, Aplikasi Analisis Multivariate dengan Program SPSS, 4th ed. Semarang: Badan Penerbit Universitas Diponegoro, 2006.

[9] S. Yamin and H. Kurniawan, Generasi Baru Mengolah Data Penelitian dengan Partial Least Square Path Modeling, Aplikasi dengan Software XLSTAT, SmartPLS dan Visual PLS. Jakarta: Salemba Infotek, 2011.

[10] T. Marlina, "Pengaruh Earning Per Share, Return On Equity, Debt To Equity Ratio dan Size Terhadap Price To Book Value," J. Ilm. Akunt. Kesatuan, vol. 1, no. 1, pp. 59-72, 2013.

[11] Nuraeni, E. A. Lau, and R. M. Haryadi, "Pengaruh Leverage, Profitability, Market Value Dan Ukuran Perusahaan Terhadap Nilai Perusahaan Property Yang Terdaftar Di BEI Tahun 20122014,” E-Journal Untag Samarinda, vol. 5, no. 3, pp. 1-10, 2016. 
[12] A. Rusli and T. Dasar, "Pengaruh Rasio Keuangan Terhadap Harga Saham Pada Perusahaan Bumn Perbankan Yang Terdaftar Di Bursa Efek Indonesia,” J. Akunt., vol. 1, no. 2, pp. 10-17, 2014.

[13] R. Febrioni, "Pengaruh Return On Assets, Return On Equity, Earning Per Share, Dan Current Ratio Terhadap Return Saham(Pada Perusahaan Yang Terdaftar Di Indeks Lq45 Di Bursa Efek Indonesia Tahun 2011-2015)," e-Proceeding Manag., vol. 3, no. 3, pp. 3439-3449, 2016.

[14] R. . Liembono, Analisis Fundamental. Jakarta: Briliant, 2015. 